\title{
Penggunaan Metode Problem Solving untuk Meningkatkan Motivasi dan Hasil Penilaian Pendidikan Kewarganegaraan Peserta Didik di Sekolah Dasar
}

\author{
Tri Juna Irawana ${ }^{1}$, Taufina ${ }^{2}$ \\ Universitas Negeri Padang, Sumatera Barat, Indonesia ${ }^{1,2}$ \\ e-mail : : trijunairawana50@ gmail.com ${ }^{1}$, taufina@ fip.unp.ac.id ${ }^{2}$
}

\begin{abstract}
Abstrak
Pendidikan Kewarganegaraan adalah salah satu mata pelajaran di Sekolah Dasar. Pembelajaran Pendidikan Kewarganegaraan memiliki tujuan agar peserta didik dapat menerapkan ilmu yang diperolehnya di dalam dalam kehidupan sehari-hari. Pendidikan Kewarganegaraan bukan hanya mata pelajaran yang hapalan yang dianggap oleh sebahagian orang. Karena permasalahan ini peneliti melakukan penelitian tentang pembelajaran Pendidikan Kewarganegaraan. Berdasarkan pengamatan di Sekolah Dasar terlihat pembelajaran Pendidikan Kewarganegaraan dilaksanakan dengan metode ceramah saja kemudian siswa ditugaskan menghapal materi. Hal ini menyebabkan motivasi belajar dan hasil penilaian pembelajaran Pendidikan Kewarganegaraan kurang memuaskan. Karena permasalahan tersebut peneliti melakukan Penelitian Tindakan Kelas dengan menggunakan metode pemecahan masalah atau metode problem solving. Penelitian ini menggunakan langkahlangkah mtode pemecahan masalah atau problem solving. Adapun langkah penggunaan metode pemecahan masalah atau problem solving secara garis besar adalah: menentukan masalah, mencari data untuk menyelesaikan permasalahan, mendapat jawaban sementara dalam penyelesaian masalah, menguji jawaban sementara dan mengambil kesimpulan dari penyelesaian masalah tersebut. Dengan menggunakan metode pemecahan masalah atau metode problem solving ini dapat membuat anak aktif dan bersemangat dalam pembelajaran, tidak hanya monoton dan membosankan. Kemudian hasil penilaian pembelajaran Pendidikan Kewarganegaraan menjadi meningkat. Hal ini dapat dilihat banyak peserta didik yang nilainya sudah di atas kriteria ketuntasan minimal.
\end{abstract}

Kata Kunci: motivasi, hasil penilaian, metode problem solving.

\section{Abstract}

Pen upbringing Kew arg anegaraan is one of the lessons in primary school. P embelajaran Civics have a goal that the students can apply the knowledge that dip erolehnya in the daily life. Citizenship Education is not only memorized subjects that are considered by some people. Because of this problem researchers conducted research on Citizenship Education learning. Berdasarka n observations in visible Elementary School learning Citizenship Education course conducted by the lecture method and then the students were assigned to memorize the material. Hal have led to the motivation to learn and learning assessment results Kewarganegar Education aan unsatisfactory. Because of these problems researchers conducted Classroom Action Research using problem solving methods or problem solving methods. This study uses steps in the method of solving problems or problem solving. A dapun step method using troubleshooting or problem solving outline is: menen tukan problem, looking for data to solve problems, get answers while in $\mathrm{p}$ en y elesaian problem, test the jaw Aban temporary and draw conclusions from the settlement of the problem. By using the problem solving method or this problem solving method can make children active and enthusiastic in learning, not just monotonous and boring. Then the results of the Citizenship Education learning assessment will increase. $\mathrm{H}$ al can be seen many learners whose value is already above the minimum completeness criteria.

Keywords: motivation, assessment results, problem solving methods

@ Jurnal Basicedu 2020

$\triangle$ Corresponding author :

Address : Perumahan Tamiang Simpang Empat Pasaman Barat

Email : trijunairawana50@gmail.com

Phone : 08137492884

ISSN 2580-3735 (Media Cetak)

ISSN 2580-1147 (Media Online) 
435 Penggunaan Metode Problem Solving untuk Meningkatkan Motivasi dan Hasil Penilaian Pendidikan Kewarganegaraan Peserta Didik di Sekolah Dasar - Tri Juna Irawana, Taufina

\section{PENDAHULUAN}

Pendidikan Kewarganegaraan adalah salah satu mata melajaran yang wajib diajarkan di sekolah dasar. Mata pelajaran Pendidikan Kewarganegaraan ini memiliki tujuan untuk peserta didik. Adapun tujuan mata pelajaran Pendidikan Kewarganegaraan ini misalnya untuk menghasilkan peserta didik yang mengetahui akan hak dan kewajibannya, Apabila kita bertanya kepada peserta didik apa itu hak, kebanyakan peserta didik tahu bahawa hak itu adalah sesuatu yang harus kita terima. Kemudian apa itu kewajiban, peserta didik juga tahu bahwa kewajiban adalah sesuatu yang harus kita kerjakan. Apa yang harus kita lakukan terlebih dahulu hak atau kewajiban? Peserta didik juga bisa menjawab kewajiban terlebih dahulu yang dikerjakan baru menuntut hak. Kemudian peserta didik juga dengan mudah menjawab apa contoh kewajiban dan apa contok dari hak.

Berdasarkan uraian di atas dapat disimpulkan secara pengetahuan siswa mengetahui atau menguasai materi Pendidikan Kewarganegaraan. Akan tetapi dalam pelaksanaannya jauh dari yang diharapkan. Seperti contoh yang telah diuraikan siswa tahu apa contoh hak dan apa cotoh kewajiban, tetapi masih sedikit peserta didik yang mau melaksanakan kewajibannya. Contoh kewajiban peserta didik kewajibannya adalah rajin belajar, mematuhi aturan yang ada di rumah, di sekolah dan di masyarakat. Dalam hal penerapan atau hasil penilaian sikap dan keterampilan masih jauh dari harapan. Sementara tujuan mata pelajaran Pendidikan Kewarganegaraan lebih diperlukan perkembangan sikap dan keterampilan daripada pengetahuan semata yang hanya sekedar mengetahui tanpa menerapkannya. Sementara itu kita di sekolah mempunyai peran sebagai lembaga pendidikan yang mengembangkan potensi-potensi peserta didik, agar mampu menjalani tugas-tugas dalam kehidupan, baik secara individual maupun social"(Fadhilaturrahmi, 2018).

Permasalahan tersebut bisa disebabkan karena proses pembelajaran yang masih mengutamakan hapalan daripada penerapan. Seperti yang peneliti lihat di lapangan pembelajaran Pendidikan Kewarganegaaraan ini biasanya peserta didik ditugaskan mencatat materimateri yang dipelajari, kemudian guru biasanya menugaskan peserta didik menghapal materi tersebut. Dalam penilaian juga biasanya penilaian pengetahuan lebih dipentingkan tanpa begitu memperhatikan tujuan yang sebenarnya dari pembelajaran Pendidikan Kewarganegaraan itu. Adapun tujuan Pendidikan adalah usaha manusia untuk menggunakan pikiran dalam menentukan tindakan sehingga diterima di masyarakat (Wedan, 2016). Untuk mencapai tujuan pendidikan tentu dibutuhkan metode pembelajaran yang bisa mencapai tujuannya. Sementara metode yang biasa digunakan guru dalam mata pelajaran Pendidikan Kewarganegaan adalah metode ceramah dan Tanya jawab.

Apabila hanya menggunakan metode Tanya jawab dan ceramah, maka siswa akan bosan dan tidak menciptakan cara belajar peserta didik yang kreatif. Sehingga pembelajaran yang sudah didapat dari yang disampaikan guru kemudian dihapal tidak akan lama melekat diingatan siswa. Oleh karena itu, guru hendaknya menggunakan berbagai metode dalam pembelajaran Pendidikan Kewarganegaraan. Supaya pembelajaran lebih menyenangkan peserta didik dan merekapun mengaplikasikan materi yang didapatnya dalam kehidupannya masing-masing. Salah satu metode pembelajaran untuk meningkatkan kognitif siswa di kelas 4,5 dan 6 adalah metode problem solving (Muzanni \& Muhyadi, 2016).

Penggunaan metode Pembelajaran yang tidak bervariasi dapat menyebabkan nilai mata pelajaran Pendidikan Kewaraganegaraan peserta 
didik kurang sesuai dengan harapan terutama ketuntasan penilaian sikap dan keterampilan. Oleh karena itu perlu dikembangkan suatu pembelajaran yang tidak membosankan. Selain itu menurut (Ananda \& Fadhilaturrahmi, 2018)“"guru juga harus melaksanakan pembelajaran yang lebih baik sesuai dengan perkembangan ilmu pengetahuan". Sehingga tujuan Pendidikan Kewarganegaraan tercapai dengan maksimal.

$$
\text { Agar tercapai tujuan Pendidikan }
$$

Kewarganegaraan tersebut tentu tidak lepas dari peranan seorang guru. Guru harus bisa menggunakan berbagai metode untuk pembelajaran Pendidikan Kewarganegaraan supaya Pendidikan Kewarganegaraan itu bukan hanya pelajaran untuk mengembangkan pengetahuan tetapi juga untu membentuk kepribadian peserta didik supaya menjadi masyarakat yang berguna bagi bangsa dan Negara.

Adapun salah satu metode yang dapat dipergunakan dalam pembelajaran Pendidikan Kewarganegaraan adalah metode pemecahan masalah atau prolem solving. Adapun metode pemecahan masalah atau problem solving. Menurut Gagne dalam (Martinis, 2008:81) problem solving atau pemecahan masalah adalah cara mempelajari sesuatu dengan cara berpikir tingkat tinggi dan yang paling tinggi tingkatannya dari cara mempelajari sesuatu yang lain. Sementara menurut (Fadillah, 2016) problem solving adalah stretegi pembelajaran yang dapat meningkatkan kreatif siswa dalam berpikir karena menggunakan masalah yang akan diselesaikan. Sedangkan (Komariah, 2011) berpendapat pembelajaran dengan menggunakan problem solving dapat menciptakan pembelajaran yang berpusat pada siswa.

Metode pemecahan masalah atau problem solving tentunya sangat sesuai digunakan pada pembelajaran Pendidikan Kewarganegaraan. Di mana dengan menggunakan metode pemecahan masalah atau problem solving ini diharapkan peserta didik dapat menyelesaikan masalahmasalahnya sendiri dalam kehidupannya, setelah terbiasa berpikir mencari penyelesaian permasalahan dalam pembelajaran, penggunaan pemecahan masalah dalam pembelajaran dapat meningkatkan kreatifitas siswa (Sari, Nofrianto, \& Amri, 2017)

Selain penggunaaan berbagai metode pada pembelajaran guru juga harus melaksanakan penilaian. Penilaian berguna untuk mengetahui sejauh mana tujuan pembelajaran tercapai dan untuk mengetahui perkembangan peserta didik secara berkelanjutan sesuai dengan pendapat Taufina (Taufina \& Chandra, 2018) "the assessment is no longer simply the achievement of goals, but it is an attempt to obtain a variety of information on a regular basis which is done continuously and comprehensively on the learning process and on the student learning outcomes either in the aspects of attitude, knowledge or skill”. Menurut (Taufina, Chandra, Fauzan, \& Ilham Syarif, 2019)Sebelum melaksanakan pembelajaran guru harus memikirkan aktivitas guru dan peserta didik dalam pembelajaran. Sedangkan (Fitria \& Idriyeni, 2017) mengemukakan penggunaan masalah dalam pembelajaran dapat meningkatkan pengetahuan dan keterampilan berpikir peserta didik. Metode problem solving dapat meningkatkan kemampuan peserta didik untuk memecahkan masalah (Ilmi, Salempa, \& Side, 2019)

\section{METODE}

Pendekatan penelitian yang digunakan adalah penelitian tindakan kelas. Penelitian ini diawali dengan observasi di lapangan. Observasi awal ini mengamati proses pembelajaran Pendidikan Kewarganegaraan di sekolah Dasar. Kemudian wawancara dengan guru kelas yang mengajarkan Pendidikan Kewarganegaraan 
437 Penggunaan Metode Problem Solving untuk Meningkatkan Motivasi dan Hasil Penilaian Pendidikan Kewarganegaraan Peserta Didik di Sekolah Dasar - Tri Juna Irawana, Taufina

tentang bagaimana proses pembelajaran

Pendidikan Kewarganegaraan kemudian

bagaimana hasil pembelajaran Pendidikan

Kewarganegaraan tersebut. Setelah melakukan observasi dan mewawancarai beberapa narasumber seperti guru, siswa, peneliti mendapatkan permasalahan. Yang mana permasalahannya adalah pembelajaran Pendidikan Kewarganegaraan kurang menarik bagi peserta didik karena metode pembelajarannya yang hanya dua arah dan lebih menekankan hapalan daripada penerapannya apa yang sudah dipelajari peserta didik itu sendiri.

Setelah menemukan permasalahan peneliti mencari cara penyelesaiannya. Yaitu merubah metode pembelajaran ceramah menjadi metode problem solving. Penelitian dilakukan dengan cara dua siklus. Karena siklus 1 belum berhasil dan setelah melakukan siklus kedua baru mencapai harapan yang memuaskan, yaitu adanya peningkatan hasil penilaian peserta didik.

Sebelum melakukan penelitian siklus 1 peneliti terlebih dahulu menyusun lembar pengamatan untuk guru, lembar pengamatan untuk peserta didik dan Rencana Pelaksaan Pembelajaran yang telah disesuaikan dengan metode problem solving atau pemecahan masalah. Sesudah mempersiapkan hal- hal di atas peneliti terjun ke lapangan yaitu ke sekolah dasar. Peneliti sebagai partisipan. Peneliti langsung ikut serta dalam penelitian,

Peneliti secara langsung mempraktekkan proses pembelajaran pemecahan masalah atau problem solving. Guru lain sebagai observer untuk mengamati kegiatan pembelajaran yang dilaksanakan kemudian guru itu mengisi lembar observasi telah disiapkan peneliti. Yaitu lembar pengamatan untuk guru, lembar pengamatan untuk peserta didik.

Setelah dilaksanakan penelitian siklus 1 diadakan perbincangan antara peneliti dengan guru yang mengamati kegiatan penelitian. Peneliti dan guru kelas membicarakan mulai dari perencanaan, pelaksaan dan hasil evaluasi kegiatan penelitian.Kemudian, didapat apa saja kekurangan dan kelebihan proses pembelajaran tersebut. Selanjutnya diambil kesimpulan pada penelitian siklus 1 masih perbaikan. Siklus 1 dievaluasi untuk pedoman melanjutkan ke siklus II.

Sebelum lanjut siklus II disusun lagi perencanaanya seperti lembar pengamatan untuk siswa, lembar pengamatan untuk peserta didik dan Rencana Pelaksanaan Pembelajaran Siklus II. Sesudah perencanaan sudah disiapkan lanjut ke pelaksanaan siklus II. Setelak selesai pelaksanaan siklus II diadakan lagi evaluasi apkah penggunaan metode pemecahan masalah atau problem solving dapat meningkatkan hasil penilaian belajar peserta didik baik di bidang pengetahuan, bidang sikap dan bidang keterampilan. Saat siklus II sudah selesai dapat diambil kesimpulan penggunaan metode problem solving atau pemecahan masalah pada pembelajaran Pendidikan Kewarganegaraan sangat efektif digunakan dan berhasil meningkatkan hasil penilaian belajar Pendidikan Kewarganegaraan di sekolah dasar.

Sumber data penelitian di ambil dari hasil pengamatan, wawancara, pencatatan lapangan dan juga dokumentasi. Dokumentasi di ambil saat pelaksanaan pembelajaran kemudian data penelitian diolah dari hasil pengamatan yang diisi pada lembar pengamatan untuk guru dan lembar pengamatan untuk siswa. Pengolahan data diambil dari mulai perencanaa, melaksanakan, evaluasi dan menganalisis proses pembelajaran menggunakan metode problem solving dan pemecahan masalah. Imron (2005:30) menguraikan Tahap menganalisis adalah langkah pertama mengumpulkan informasi, mengumpulkan informasi ini bisa diperoleh dari wawancara, pengamatan, dokumentasi, tahap selanjutnya setelah mengumpulkan informasi adalah memilih data yang penting untuk digunakan dan membuang yang tidak penting, selanjutnya 
adalah menyajikan data yang sudah ditetapkan dan membicarakannya dengan para ahli, teman sejawat dan beberapa guru. Tahap menganalisis ini berguna untuk menemukan permasalahan dan cara penyelesaiannya.

\section{HASIL DAN PEMBAHASAN}

Kegiatan penelitian tentang penggunaan metode prolem solving untuk meningkatkan hasil penilaian pembelajaran Pendidikan Kewarganegaraan ini dilaksanakan sebanyak dua siklus di kelas IV Sekolah Dasar.

Tahap perencanaan ini peneliti merencanakan apa saja yang akan dilaksanakan pada pembelajaran dengan menggunakan metode problem solving di kelas IV Sekolah Dasar. Peneliti menggunakan langkah langkah pembelajaran menggunakan metode problem solving di dalam rencana pelaksanaan pembelajaran. Setelah menyusun rencana pelaksanaan pembelajaran yang sesuai dengan urutan penggunaan metode problem solving, peneliti menyusun lembar pengamatan untuk mengamati kegitan guru dan lembar pengamatan untuk mengamati kegitan siswa. Peneliti juga menyiapkan kriteria penilaian tes pengetahuan, sikap dan keterampilan.

Pelaksanaan penelitian dilakukan sesuai dengan perencanaan yang telah tersusun. Pelaksanaan pembelajaran diamati dan lembar pengamatan untuk guru dan lembar pengamatan untuk siswa diisi sesuai dengan cara mengisi lembar pengamatan yang telah dibuat. Pelaksanaan pembelajaran dengan menggunakan metode problem solving di kelas IV ini diamati oleh dua orang guru dan satu orang teman sejawat. Peneliti bertindak langsung sebagai guru saat pembelajaran Pendidikan Kewarganegaraan menggunakan metode Problem solving. Dua orang guru mengisi lembar pengamatan yang telah disediakan, sedangkan teman sejawat mengambil photo untuk dokumentasi.

Adapun langkah-langkah pembelajaran pada siklus 1 ini adalah: Kegiatan awal yang dilakukan guru adalah menugaskan peserta didik berdoa, mencek kehadiran peserta didik, melakukan tanya jawab tentang pembelajaran sebelumnya dan mengaikan dengan pembelajaran yang akan dilaksanakan. Saat pembelajaran guru membagi siswa menjadi beberapa kelompok, menurut (Maksum, 2011) siswa yang belajar secara berkelompok, menggunakan beberapa metode, dan fortofolio dapat meningkatkan kecakapan dan karakter peserta didik. Adapun materinya adalah tentang pengaruh globalisai. Selanjutnya guru menyampaikan kepada peserta didik tujuan pembelajaran. Salah satunya adalah dapat menghindari pengaruh negatif dari globalisas.

Kegiatan inti peserta didik mengikuti langkahlangkah pembelajaran dengan menggunakan metode problem solving. Adapun langkah penggunaan metode problem solving pada kegiatan pembelajaran adalah: Adanya masalah yang jelas untuk dipecahkan Peserta didik diminta untuk memperhatikan gambar globalisasi yang dipajang, peserta didik memberikan tanggapan tentang gambar yang dipajang guru, kemudian guru meminta peserta didik menunjuk tangan siapa yang bisa menceritakan masalah yang ada pada gambar, hanya beberapa orang yang menunjuk tangan, kemudian peserta didik menunjuk satu gambar dan menceritakan gambar tentang pengaruh globalisasi yaitu gambar HP. Kemudian peserta didik melakukan tanya jawab contohcontoh masalah globalisasi yang terjadi di kota Padang. Kegiatan pembelajaran dilanjutkankan dengan tanya jawab tentang pengertian globalisasi, peserta didik menjelaskan pengertian globalisasi dengan kata-kata mereka sendiri. Selanjutnya peserta didik dibagi menjadi beberapa kelompok. 
Selanjutnya peserta didik mencari data atau masalah yang jelas untuk dipecahkan.Diskusi dilanjutkan dengan mendiskusikan cara menyelesaikan permasalahan yang ditimbulkan dari globalisasi. Peserta didik bekerja sama dan saling bertanya serta mengeluarkan pendapat masing-masing, sehingga peserta didik dapat menetapkan jawaban dari hasil diskusinya dari masalah globalisasi. Setiap jawaban hasil diskusinya yang ditemukan dicatat ke dalam LKS yang dipegang oleh peserta didik. Setelah diskusi dilaksanakan peserta didik melaporkan hasil diskusinya tentang jawaban yang telah di dapat dari diskusi tentang penyelesaian masalah globalisasi dan kelompok lain menanggapinya.

Langkah selanjutnya adalah mencari jawaban sementara.Pada tahap ini peserta didik melanjutkan pembelajaran dengan melanjutkan diskusi kelompok. Dalam diskusi kelompok setiap anggota memberikan informasi yang diperolehnya tentang pengaruh globalisasi yang terjadi di kota Padang dengan membaca berbagai macam buku untuk mencari informasi dan pengetahuan tentng permasalahan yang timbul dari globalisasi. Peserta didik bertukar pikiran tentang apa yang telah mereka dapatkan. Data-data yang diperoleh dicatat untuk dipergunakan dalam menguji hipotesis.

Menguji kebenaran jawaban sementara berdasarkan data yang telah dikumpulkan, peserta didik memilih jawaban sementara mana yang diterima dan jawaban sementara mana yang ditolak. Jawaban sementara yang telah diperoleh peserta didik dicocokkan dengan data-data yang diperoleh. Sehingga mendapatkan suatu pemecahan (solusi) yang tepat untuk memecahkan masalah globalisasi.

Mengambil keputusan, kegiatan dilanjutkan dengan menyajikan hasil diskusi kelompok ke depan kelas secara bergiliran. Guru menugaskan kelompok lain menanggapi hasil diskusi dari kelompok yang sedang menyajikan hasil diskusinya. Berdasarkan tanggapan dari kelompok lain inilah masing-masing kelompok memperbaiki hasil diskusinya. Dari 2 kelompok yang ada hanya 1 kelompok yang ke depan untuk melaporkan hasil diskusinya, sedangkan kelompok yang satu lagi kurang berani. Saat melaporkan diskusi peserta didik malu-malu ke depan dan suara mereka kurang terdengar oleh teman yang lain. Setelah melaporkan hasil diskusinya peserta didik bersama guru menyepakati solusi pemecahan masalah globalisasi yaitu beribadah dengan tekun, belajar bahasa asing, belajar komputer, memilahmilah acara televisi, menggunakan internet sebagai sarana dalam belajar. Kegiatan ini diakhiri dengan mendengarkan penjelasan tentang pentingnya melakasanakan solusi yang telah ditetapkan. Sumua peserta didik tampak serius mendengarkan penjelasan guru.

Kegiatan Akhir,diteruskan dengan sesi tanya jawab tentang pembelajaran yang belum dikuasai oleh peserta didik. Tindak lanjut yaitu peserta didik peserta didik diberi tugas membuat kliping, menyimpulkan pembelajaran, pelajaran disimpulkan dengan mengadakan tanya jawab antar guru dan peserta didik tentang materi yang telah dikuasai peserta didik. Kegiatan penutup ditutup dengan kegitan evaluasi.

Mengamati, saat proses pengamatan, setiap butir-buti pengamatan diisi sesuai dengan yang diamati. Pengamatan untuk kegiatan peserta didik diamati oleh satu orang guru, sedangkan satu orang guru lagi mengamati kegitan yang dilaksanakan guru.

Setelah proses pengamatan diadakan diskusi antara peneliti dengan observer atau pengamat. Lembar pengamatan yang telah didiisi dibahas bersama untuk mengetahui apa kekurangan dari kegiatan pembelajaran pada siklus 1 dan memperbaiki rencana pelaksanaan pembelajaran di siklus berikutnya. Pada pelaksanaan pembelajaran dengan penggunaan metode problem solving pada 
siklus 1 ini didapatkan kesimpulan bahwa sudah ada peningkatan hasil penilain pembelajaran. Akan tetapi, masih perlu perbaikan supaya hasilnya lebih memuaskan. Jadi, diperbaikilah kegiatan pembelajaran pada siklus II.

Pembahasan Siklus II perencanaan Penggunaan metode problem solving dalam perencanaan pembelajaran Pendidikan Kewarganegaraan disusun dalam bentuk Rencana Pelaksanaan Pembelajaran. Perencanaan yang dibuat pada siklus II hampir sama dengan perencanaan pembelajaran siklus I. Bedanya terletak pada, pengembangan materi pembelajaran yang disesuaikan dengan tujuan pembelajaran, pengembangan butir soal penilaian/evaluasi tes akhir.

Penilaian terhadap pembelajaran disiklus II ini adalah dengan memberikan latihan diakhir pembelajaran. Latihan tersebut rencananya untuk menentukan skor akhir yang diperoleh pada siklus II dan berguna untuk melihat keberhasilan dari siklus II ini. Untuk mencapai tujuan tersebut rencana pelaksanaan pembelajaran dibagi menjadi tiga tahap yaitu: 1) kegiatan awal, 2) kegiatan inti, 3) kegiatan akhir. Ketiga kegiatan ini tidak berdiri sendiri melainkan terkait antara kegiatan satu dengan kegiatan lainnya.

Kegiatan yang direncanakan guru siklus II pada kegiatan awal adalah menyiapkan peserta didik untuk belajar, berdo'a dan mencek kehadiran peserta didik, apersepsi yaitu membangkitkan skemata peserta didik dengan tanya jawab tentang contoh-contoh pengaruh globalisasi, dan menginformasikan tujuan pembelajaran.

Pada kegiatan inti kegiatan yang dilaksanakan guru adalah melaksanakan langkah-langkah problem solving, yaitu:

Adanya masalah yang jelas untuk dipecahkan

Peserta didik memperhatikan gambar pengaruh globalisasi di depan kelas yang dipajangkan guru. Gambar yang dipajang diberi warna yang menarik. Kemudian peserta didik melakukan tanya jawab tentang gambar. Tanya jawab tentang masalah yang diakibatkan globalisasi. Peserta didik diminta untuk menyebutkan contoh-contoh masalah globalisasi yang telah diketahuinya. Setelah peserta didik melakukan tanya jawab tentang gambar, barulah peserta didik menentukan masalah yang akan mereka pecahkan. yaitu masalah globalisasi. Peserta didik dibagi ke dalam 2 kelompok. Peserta didik mendengarkan penjelasan guru apa saja yang didiskusikan peserta didik dalam kelompok. Guru membagikan LKS kepada setiap kelompok.

Mencari data atau keterangan untuk memecahkan masalah.Peserta didik membicarakan berbagai kemungkinan pemecahan masalah yang ditimbulkan globalisasi sesuai dengan pengetahuan yang dimilikinya dibawah bimbingan guru dalam kelompok masing-masing. Kemudian peserta didik membuat jawaban hasil diskusi penyebab timbulnya masalah yang diakibatkan globalisasi di dalam LKS yang telah diberikan. Setelah diskusi peserta didik melaporkan hasil diskusi tentang jawaban yang mereka kemukakan ke depan kelas dan kelompok lain menanggapi hasil laporan kelompok temannya.

Mencari jawaban sementara. Peserta didik melanjutkan diskusi untuk mencari pengetahuan atau keterangan yang berkaitan dengan masalah yang diakibatkan globalisasi agar dapat digunakan untuk memecahkan masalah yang diakibatkan globalisasi baik dengan membaca berbagai macam buku dan diskusi dengan temannya.

Menguji kebenaran jawaban sementara setelah memperoleh data dari berbagai sumber. Peserta didik mendiskusikan kembali solusi yang telah dikemukakan dengan pengetahuan yang diperoleh. Solusi yang tidak tepat dicoret.

Mengambil keputusan, pada tahap ini peserta didik melaporkan hasil diskusi ke depan kelas, dan hasil laporan tersebut kemudian ditanggapi oleh 
kelompok lain. Dari hasil tanggapan tersebut peserta didik memperbaiki hasil kerja kelompoknya. Sehingga masalah yang diakibatkan globalisasi dapat dipecahkan. Setelah peserta didik melaporkan hasil diskusi dan dibahas bersamasama dengan guru, maka dari hasil diskusi tersebut peserta didik dapat mengambil suatu kesimpulan terakhir tentang jawaban dari masalah yang diakibatkan globalisasi kemudian peserta didik mendengarkan penjelasan tentang pentingnya melaksanakan solusi yang telah ditetapkan.

Kegiatan yang direncanakan pada kegiatan akhir adalah melaksanakan komponen terakhir dari rencana pelaksanaan pembelajaran ini adalah evaluasi, evaluasi dilakukan terhadap proses dan hasil.

Pelaksanaan di siklus ke II guru lebih memberikan semangat kepada peserta didik untuk lebih aktif dalam berdiskusi dan memberikan nilai tambah bagi siswa yang aktif di kelompoknya. Peserta didik terlihat tambah bersemangat dalam kegiatan pembelajaran.

Berdasarkan penelitian yang dilakukan peneliti dapat diambil kesimpulan bahwa kegiatan pembelajaran Pendidikan Kewarganegaraan dengan menggunakan metode problem solving dapat meningkatkan motivasi belajar peserta didik. Hal ini terlihat saat pembelajaran peserta didik terlihat aktif ingin mencari tahu cara memecahkan masalah yang telah dipilih. Pembelajaran Pendidikan Kewarganegaraan bukan hanya pembelajaran dianggap sebahagian orang sebagai mata pelajaran hapalan.

Pembelajaran dengan menggunakan metode problem solving ini juga dapat meningkatkan hasil penilaian peserta didik. Misalnya terlihat nilai pengetahuan semakin meningkat, hal ini mungkin disebabkan karena peserta didik yang mencari sendiri tentang cara menghadapi globalisasi, jadi ingatan peserta didik terhadap materi pembelajaran semankin baik. Sesuai dengan pendapat
Muhammadi dan Taufina (Muhammadi, Taufina, \& Chandra, 2018)"kreatifitas peserta didik akan meningkat apabila peserta didik yang menemukan sendiri”. Demikian juga penilaian sikap dan keterampilannya semakin meningkat, hal ini terlihat saat berdiskusi peserta didik sudah mau aktif dan tidak lagi malu-malu mengeluarkan pendapat dan tertib saat berdiskusi. Jadi hasil penilaian Pembelajaran Pendidikan Kewarganegaraan mengalami peningkatan. Menurut Mehrens dan Lehmann (dalam Ngalim, 2006:3) penilaian adalah " cara membuat suatu kesimpulan yang melalui proses perencanaan dan informasi. Kemudian Sebagai mana yang dikatakan oleh Ngalim (2006:18) bahwa “ peserta didik hasil belajarnya bisa diperoleh dari pengetahuan, pemahaman, penerapan, menganalisis dan penilaian". "Selain itu penilaian merupakan proses menggambarkan perubahan siswa dalam pembelajaran" Taufina dan Subroto (Taufina \& Subroto, 2016). Selanjutnya(Widyawati, 2015) juga berpendapat dalam menggunakan pendekatan dimasukkan problem solving dapat meningkatkan hasil belajar peserta didik.

\section{SIMPULAN}

Berdasarkan hasil penelitian dapat diambil kesimpulan pembelajaran dengan penggunaan metode problem solving dapat meningkatkan motivasi belajar peserta didik dan meningkatkan hasil penilaian peserta didik. Langkah kegitan dalam pembelajaran metode problem solving adalah yang pertama adanya masalah yang akan dipecahkan. Kemudian yang kedua mencari informasi atau data untuk menyelesaikan masalah tersebut. Selanjutnya yang ketiga menguji permasalahan dengan informasi yang di dapat serta membuat jawaban untuk sementara. Selanjutnya diujicoba dan diambil kesimpulan. 
442 Penggunaan Metode Problem Solving untuk Meningkatkan Motivasi dan Hasil Penilaian Pendidikan Kewarganegaraan Peserta Didik di Sekolah Dasar - Tri Juna Irawana, Taufina

\section{DAFTAR PUSTAKA}

Ananda, R., \& Fadhilaturrahmi, F. (2018). ANALISIS KEMAMPUAN GURU SEKOLAH DASAR DALAM IMPLEMENTASI PEMBELAJARAN TEMATIK DI SD. Jurnal Basicedu. https://doi.org/10.31004/basicedu.v2i2.42

Fadhilaturrahmi, F. (2018). LINGKUNGAN BELAJAR EFEKTIF BAGI SISWA SEKOLAH DASAR. Jurnal Basicedu. https://doi.org/10.31004/basicedu.v2i2.52

Fadillah, A. (2016). PENGARUH PEMBELAJARAN PROBLEM SOLVING TERHADAP KEMAMPUAN BERPIKIR KREATIF MATEMATIS SISWA. FIBONACCI: Jurnal Pendidikan Matematika Dan https://doi.org/10.24853/fbc.2.1.1-8

Matematika.

Fitria, Y., \& Idriyeni, I. (2017). DEVELOPMENT OF PROBLEM-BASED TEACHING MATERIALS FOR THE FIFTH GRADERS OF PRIMARY SCHOOL. Ta'dib. https://doi.org/10.31958/jt.v20i2.747

Ilmi, N., Salempa, P., \& Side, S. (2019). Penerapan Model Pembelajaran Learning Cycle $5 \mathrm{E}$ y ang Terintegrasi dengan Metode Problem Solving The Application of Learning Cycle 5E Model which was Integrated with Problem Solving Method. Jurnal Sainsmat.

Komariah, K. (2011). Penerapan Metode Pembelajaran Problem Solving Model Polya Untuk Meningkatkan Kemampuan Memecahkan Masalah Bagi Siswa Kelas IX J Di SMPN 3 Cimahi. Prosiding Seminar Nasional Penelitian, Pendidikan Dan Penerapan MIPA, Fakultas MIPA, Universitas Negeri Yogyakarta.

Maksum, H. (2011). Model Project Citizen Untuk Meningkatkan Kecakapan Pendidikan Kewarganegaraan Dalam Mengembangkan Sikap Nasionalisme. Jurnal Pendidikan Serambi Ilmu (Wadah Informasi Ilmiah Dan Kreativitas Intelektual Pendidikan).

Muhammadi, M., Taufina, T., \& Chandra, C. (2018). LITERASI MEMBACA UNTUK MEMANTAPKAN NILAI SOSIAL SISWA SD.

LITERA https://doi.org/10.21831/ltr.v17i2.16830

Muzanni, A., \& Muhyadi, M. (2016). PENGEMBANGAN PERANGKAT PEMBELAJARAN PROBLEM SOLVING MATA PELAJARAN IPA TERHADAP
HASIL BELAJAR KOGNITIF SISWA SD. Jurnal Prima Edukasia. https://doi.org/10.21831/jpe.v4i1.7746

Sari, I. P., Nofrianto, A., \& Amri, M. A. (2017). Creative Problem Solving: Bagaimana Pengaruhnya terhadap Kreativitas Siswa? Jurnal Elemen. https://doi.org/10.29408/jel.v3i1.340

Taufina, \& Subroto, W. T. (2016). The application of authentic assessment in integrated thematic teaching and learning process in elementary school level. International Journal of Control Theory and Applications.

Taufina, T., \& Chandra, C. (2018). The Implication of Authentic Assessment in Thematic Integrated Learning Process at Lower Level Elementary School Early Childhood Development. https://doi.org/10.2991/icece-17.2018.36

Taufina, T., Chandra, C., Fauzan, A., \& Ilham Syarif, M. (2019). Development of Statistics in Elementary School Based RME Approach with Problem Solving for Revolution Industry 4.0. https://doi.org/10.2991/icet-19.2019.172

Wedan, M. (2016). Pengertian Pendidikan dan Tujuan Pendidikan Secara Umum.

Widyawati, H. (2015). PENINGKATAN HASIL BELAJAR TEMA SEHAT ITU PENTING MENGGUNAKAN MODEL PROBLEM SOLVING PADA SISWA KELAS 5 SDN NGENING 01, BATANGAN - PATI TAHUN 2014-2015. Scholaria: Jurnal Pendidikan Dan Kebudayaan. https://doi.org/10.24246/j.scholaria.2015.v5.i 3.p1-11

Etin Solihatin dan Raharjo. 2008. Cooperatif Learning Analisis Pembelajaran IPS. Jakarta: Bumi Aksara.

Imron Rosidi.2005. Ayo Senang Menulis Karya Tulis Ilmiah. Jakarta: Media Pustaka.

Martinis Yamin dan Bansu Ansari.2008. Taktik Mengembangkan Kemampuan Individual Siswa. Jakarta: Gaung Persada Press.

M. Ngalim Purwanto.2006. Prinsip-Prinsip dan Teknik Evaluasi Pengajaran. Bandung: PT. Remaja Rosdakarya.

Nurhadi.2002. Pembelajaran Kontekstual. Jakarta: Depdiknas 